Collins (1966) mentioned changes of an inflammatory character causing joint enlargement. Our patient had definite recurrent synovial effusions, but the cytology proved that this was not an inflammatory fluid. Synovial biopsy also revealed an absence of cellular infiltration and only minimal synovial cell hyperplasia. Thus, in this case, in spite of effusions in multiple ioints, there was no pathological evidence of inflammatory arthritis. It is possible that the effusion was an oversecretion due to the increased vascularity of the synovium where it is in contact with the underlying hypervascular periosteum.

\section{Acknowledgments}

We wish to thank Dr C. Tribe for his help with the pathology, Mr E. F. J. Ring for his skilled technical assistance with thermographic examinations, and Winthrop Laboratories for their support in purchasing the thermographic apparatus. G.R. was in receipt of a grant from the Arthritis and Rheumatism Council.

\section{References}

BAMBERGER, E. VON (1889) Bronchiektasie. Wiener klinische Wochenschrift, 2, 226

Collins, A.J., Ring, E.F.J., Cosh, J.A. \& BACon, P.A. (1974) Quantitation of thermography in arthritis using multiisothermal analysis. I. The thermographic index. Annals of the Rheumatic Diseases, 33, 2, 113.

Collins, D. (1966) Pathology of Bone, p. 75. Butterworths: London.
Cudkowicz, L. \& Armstrong, J.B. (1953) Finger clubbing and changes in the bronchial circulation. British Journal of Tuberculosis and Diseases of the Chest, 47, 227.

DrAPER, J.W. \& BOAG, J.W. (1971) Skin temperature distributions over veins and tumours. Physics in Medicine and Biology, 16, 4, 645 .

FRIED, B.K. (1943) Chronic pulmonary osteoarthropathy: dyspituitarism as a probable cause. Archives of Internal Medicine, 72, 565.

GinsBURG, J. (1963) Hypertrophic pulmonary osteoarthropathy. Postgraduate Medical Journal, 39, 639.

GINSBURG, J. \& BROWN, J.B. (1961) Increased oestrogen excretion in hypertrophic pulmonary osteoarthropathy. Lancet, ii, 1274.

HaLl, G.R. (1959) The cause of digital clubbing. Lancet, i, 750.

KUNKel, G. (1971) Hypertrophe pulmonale, Osteoarthropathie (HPO) und venöse Beimischung. Klinische Wochenschrift, 49, 739.

LOVELL, R.R.H. (1950) Observations on structure of clubbed fingers. Clinical Science, 3, 299.

MARIE, P. (1890) De l'ostéo-arthropathie hypertrophiante pneumonique. Revue de médecine, 10, 1.

Pattison, J.D., Toledo, O., Beck, E. \& Miller, W.B. (1951) Hypertrophic osteoarthropathy in carcinoma of the lung. Journal of the American Medical Association, 152, 783.

Ring, E.F.J., Collins, A.J., BAcon, P.A. \& Cosh, J.A. (1974) Quantitation of thermography in arthritis using multi-isothermal analysis. II. Effect of non-steroidal antiinflammatory therapy on the thermographic index. Annals of the Rheumatic Diseases, 33, 4, 353.

Wierman, W.H., Clagetr, O.T. \& McDonald, J.R. (1954) Articular manifestations in pulmonary diseases. Journal of the American Medical Association, 155, 17, 1459.

\title{
Progressive systemic sclerosis and autoimmune haemolytic anaemia
}

\author{
E. Sumithran * \\ M.B., B.S. \\ Department of Medicine, University Hospital, Kuala Lumpur, Malaysia
}

\begin{abstract}
Summary
The development of progressive systemic sclerosis (PSS) in a patient with established autoimmune haemolytic anaemia is described. Points favouring an immunological aetiology for PSS are reviewed and discussed.
\end{abstract}

SinCE the first report by Fundenberg and Wintrobe (1955) describing the association between progressive systemic sclerosis (PSS) and autoimmune haemolytic

* Present address: Department of Pathology, Medical Faculty, University of Malaya, Kuala Lumpur. anaemia, other similar cases have been reported (Steiner, Haeger-Aronsen and Nielson, 1967; Westerman et al., 1968; Chaves et al., 1970; Ivey et al., 1971; Rosenthal and Sack, 1971). All reported cases presented initially with features of PSS and were only later complicated by autoimmune haemo lytic anaemia. In 1973, Loft and Olsen described a case which presented with autoimmune haemolytic anaemia but had on examination features of PSS as well. In none of the previously reported cases had autoimmune haemolytic anaemia preceded the development of PSS. 
This case report describes the development of PSS in a patient with established autoimmune haemolytic anaemia.

\section{Case report}

A 24-year-old Chinese female first presented with jaundice and anaemia and was treated symptomatically by a private doctor. She was not fully investigated at that time. A second episode of jaundice and anaemia occurred 15 months later, when she was admitted to the University Hospital, Kuala Lumpur, with exertional dyspnoea, malaise and lethargy. Physical examination revealed her to be clinically anaemic and mildly icteric. The skin appeared normal. Cardiac and pulmonary findings were normal. The liver was not enlarged but the spleen was palpable $2 \mathrm{~cm}$ below the costal margin. Laboratory investigations revealed $\mathrm{Hb} 7 \cdot 2 \mathrm{~g} / 100 \mathrm{ml}$; MCHC $30 \%$; reticulocytes $10.2 \%$; WBC $4900 / \mu \mathrm{l}$ (neutrophils $89 \%$, lymphocytes $6 \%$, monocytes $3 \%$, eosinophils $2 \%$ ); platelet count $212,000 / \mu \mathrm{l}$. The ESR (Westergren) was $122 \mathrm{~mm} / \mathrm{hr}$. The urine contained urobilinogen but not bilirubin. Serum total bilirubin was $2.9 \mathrm{mg} / 100 \mathrm{ml}$ and unconjugated bilirubin $2.6 \mathrm{mg} / \mathrm{ml}$. The direct Coombs' test was repeatedly positive. The direct Coombs' test positive red cells gave eluates which reacted with papain sensitized red cells maximally at $4^{\circ} \mathrm{C}$. Plasma protein electrophoresis showed raised $\gamma$-globulins. Immunoelectrophoresis showed an increase in IgM. The red blood cells showed autoagglutination as well as rouleaux formation at $4^{\circ} \mathrm{C}$. The cold agglutinins in the serum showed no demonstrable specificity. Repeated examinations for LE cells, antinuclear antibody and rheumatoid factor were all negative. The Donath-Landsteiner and VDRL tests were also negative. A diagnosis of autoimmune haemolytic anaemia was made. Treatment with prednisolone $60 \mathrm{mg} /$ day was commenced with fairly good response. The haemolysis was controlled and the ESR became normal. She was maintained on prednisolone 10 $\mathrm{mg}$ /day and regularly followed-up at the Haematology Clinic.

Two years later she first complained that her fingertips became blue and painful on exposure to the cold. The skin over her fingertips was noted to be pale. Further observation confirmed Raynaud's phenomenon.

Six months later, she was found to have thickening of the skin of the fingers of both hands. PSS was suspected and confirmed by skin biopsy.

Within a year, the skin of both forearms had become involved and there was some loss of mobility of facial skin. She also developed dysphagia but barium studies to demonstrate oesophageal involvement were deferred because the patient was pregnant at that time.

\section{Discussion}

This case report describes the development of PSS in a patient with established autoimmune haemo $\frac{2}{C}$ lytic anaemia.

Despite numerous theories concerning aetiologys and pathogenesis, the fundamental nature of PSSO remains obscure. However, the demonstration of several immunological abnormalities in PSS (Roth $\frac{\bar{s}}{7}$ field and Rodnan, 1968), together with the associa- $-{ }^{\circ}$ tion of PSS with disorders of known immunologicab origin, has strengthened the view that aberrants immunity may be important in pathogenesis.

In PSS, inflammatory and vascular lesionsresembling those seen in other immunologicalo connective tissue diseases have been described. In flammation is present most frequently in the form of $\overline{\text {. }}$. synovitis, and synovial biopsy examination early ini the course of the disease has revealed an inflam-is matory reaction characterized by the infiltration of lymphocytes, plasma cells and smaller numbers of polymorphs. The appearance of the synovium atw this time is not unlike that observed in milder cases? of rheumatoid arthritis (Rodnan, 1963). Vascular changes may occur in the small vessels of the lungs 3 heart, gastrointestinal tract, striated muscle anc5 kidneys of patients with PSS (Rodnan, 1963). The renal vascular lesions consist of intimal hyperpla\&ace of the interlobular arteries and fibrinoid necrosis afferent arterioles and glomerular tufts. Schafer a⿳亠二口犬d Schafer (1968) found that 7S $\gamma$-globulin may occtrrs in the fibrinoid material in the kidneys, while McGiven, deBoer and Barnett (1971) demonstrated collections of immunoglobulins (predominantly응 IgM) and complement in the basement membrane region of glomeruli of patients with PSS. $\beta_{1 \mathrm{c}}$ globulin的 deposition was found by Stone et al. (1974) in the mesangium and tubular basement membranes of their patient with PSS complicated by acute renat failure.

Hypergammaglobulinaemia occurs in about $50 \%$ of patients with PSS (Rodnan, 1963). The increase usually involves IgG; less often elevations of $\operatorname{IgA}$ and IgM (Rothfield and Rodnan, 1968). Between 25\% and $33 \%$ of patients with PSS have positive testso for rheumatoid factor, and antinuclear antibodies are demonstrable in $75 \%$ or more patients (Rothfieldo and Rodnan, 1968). Positive LE cell reactions and false positive serological reactions for syphilis have $\mathrm{N}$ been recorded (Rodnan, 1963).

A picture similar to PSS has been produced in rats N్ by the injection of homologous lymphocytes into ao recipient which had previously been made tolerant to these cells (Stastny, Stembridge and Ziff, 1963). The fact that PSS can be produced in experimental $\stackrel{\infty}{+}$ animals by the injection of immunologically active 0 cells which react against the recipient but cannot be reiected, suggests an immunological mechanism $\stackrel{\odot}{\odot}$ 
in this disease (Turk, 1972). Thymic changes have also been noted in PSS. Biggert and Nevin (1967) described the thymus in PSS as hyperplastic with numerous Hassall's corpuscles, medullary lymphoid follicles and plasma cells, features interpreted as evidence of disturbed immunological function. Lymphocyte toxicity to muscle, fibroblasts and epithelial cells has been described in PSS (Currie, Saunders and Knowles, 1971) and, using the leucocyte migration tests, Hughes, Holt and Rowell (1974) have demonstrated widespread cell-mediated hypersensitivity in PSS to human tissue antigens.

An indirect but strong argument favouring immunopathogenesis is the contribution of PSS to the 'overlap syndromes'. PSS has been associated with rheumatoid arthritis, systemic lupus erythematosus (SLE), Sjögren's syndrome, dermatomyositis, Hashimoto's thyroiditis and hypogammaglobulinaemia (Miescher and Muller-Eberhard, 1969). In 'mixed connective tissue disease', patients may present with features of PSS and clinical and serological features highly suggestive of SLE, and often exhibit a specific antibody to an extractable nuclear antigen (Sharp et al., 1971). PSS has also been reported in association with primary biliary cirrhosis (Reynolds et al., 1971) and it has been suggested that this association may be due to a common autoimmune process (Murray-Lyon et al., 1970).

Haemolytic anaemia has been described as the first symptom in periarteritis nodosa (PAN) and as a chronic complication of PAN (Dameshek and Rosenthal, 1951; Lovshin, 1952). Autoimmune haemolytic anaemia is well documented as a feature of SLE and has been known to follow or precede other symptoms of SLE by a number of years (Dubois, 1952). The same may occur in PSS. There are now at least eight reported cases of PSS associated with autoimmune haemolytic anaemia; an association which together with other immune phenomena suggests a basic immunological disorder. This case demonstrates that autoimmune haemolytic anaemia may be the first symptom of PSS and may precede Raynaud's phenomenon and skin changes of PSS by a number of years.

\section{Acknowledgments}

I wish to thank Associate Professor H. O. Wong and Professor K. S. Lau for permission to publish this case, and Associate Professor J. C. White for the haematological investigations. I am grateful to Dr A. L. Vaterlaws and Professor R. A. B. Drury for their encouragement and advice.

\section{References}

Biggert, J.D. \& Nevin, N.C. (1967) Hyperplasia of the thymus in progressive systemic sclerosis. Journal of Pathology and Bacteriology, 93, 334.
Carter, J., Ewen, S.W.B., Gray, E. \& BeCK, J.S. (1973) The thymus in systemic sclerosis. Journal of Pathology, 110, 97.

Chaves, F.C., Rodrigo, F.G., Franco, M.L. \& Esteves, J. (1970) Systemic sclerosis associated with autoimmune haemolytic anaemia. British Journal of Dermatology, 82, 298.

Currie, S., Saunders, M. \& KNowles, M. (1971) Immunological aspects of systemic sclerosis: in vitro activity of lymphocytes from patients with the disorder. British Journal of Dermatology, 84, 400.

DAmesheK, W. \& Rosenthal, M.C. (1951) The treatment of acquired hemolytic anemia. Medical Clinics of North America, 35, 1423.

DuboIs, E.L. (1952) Acquired hemolytic anemia as the presenting syndrome of lupus erythematosus disseminatus. American Journal of Medicine, 12, 197.

FundenberG, H. \& Wintrobe, M.M. (1955) Scleroderma with symptomatic hemolytic anemia: a case report. Annals of Internal Medicine, 43, 201.

Hughes, P., Holt, S. \& Rowell, N.R. (1974) Leucocyte migration inhibition in progressive systemic sclerosis. British Journal of Dermatology, 94, 1.

IVEY, K.J., HWANG, Y.F. \& SHEETS, R.F. (1971) Scleroderma associated with thrombocytopenia and Coombs' positive hemolytic anemia. American Journal of Medicine, 51, 815.

LOFT, B. \& Olsen, F. (1973) Autoimmune haemolytic anaemia with positive Ham and Crosby's test and scleroderma. Scandinavian Journal of Haematology, 11, 131.

Lovshin, L.L. (1952) Association of acquired hemolytic anemia with periarteritis nodosa. Cleveland Clinic Quarterly, 19, 28.

McGiven, A.R., DeBoer, W.G.R.M. \& BARnetT, A.J. (1971) Renal immune deposits in scleroderma. Pathology, 3, 145.

Miescher, P.A. \& Muller-Eberhard, H.J. (1969) Textbook of Immunology, Vol. 2, p. 719. Grune \& Stratton: New York.

MuRRAy-Lyon, I.M., ThOMPSON, R.P.H., ANSELl, I.D. \& Williams, R. (1970) Scleroderma and primary biliary cirrhosis. British Medical Journal, 3, 258.

Reynolds, T.B., Denison, E.K., Frankl, H.D., Lieberman, F.L. \& Peters, R.L. (1971) Primary biliary cirrhosis and scleroderma, Raynaud's phenomenon and telangiectasia. American Journal of Medicine, 50, 302.

RoDNAN, G.P. (1963) A review of recent observations and current theories on the aetiology and pathogenesis of progressive systemic sclerosis. Journal of Chronic Diseases, 16, 929.

Rosenthal, D.S. \& SACK, B. (1971) Autoimmune hemolytic anemia in scleroderma. Journal of the American Medical Association, 216, 2011.

RothField, N.F. \& RodNAN, G.P. (1968) Serum antinuclear antibodies in systemic sclerosis. Arthritis and Rheumatism, 11, 607.

Sharp, G.C., Irvin, W.S., TaN, E.M., Gould, R.G. \& Holman, H.R. (1971) Mixed connective tissue disease-an apparently distinct rheumatic disease syndrome associated with a specific antibody to an extractable nuclear antigen. American Journal of Medicine, 52, 148.

Schafer, H.E. \& Schafer, A. (1968) Die progressive Sklerodermie und die terminale Phase der malignen Hypertonie. Archiv für klinische Medizin (Berlin), 214, 187.

Stastny, P., Stembridge, V.A. \& Ziff, M. (1963) Homologous disease in the adult rat, a model for autoimmune disease. I. General features and cutaneous lesions. Journal of Experimental Medicine, 118, 635.

Steiner, H., Haeger-Aronsen, B. \& Nielson, G. (1967) Porphyria cutanea tarda, Sklerodermie, Leukopenie und hämolitische Anämie. Schweizerische medizinische Wochenschrift, 97, 538. 
Stone, R.A., Tisher, C.G., Hawkin, H.K. \& Robinson, R.R. (1974) Juxtaglomerular hyperplasia and hyperreninemia in progressive systemic sclerosis complicated by acute renal failure. American Journal of Medicine, 56, 119.

TURK, J.L. (1972) Immunology in Clinical Medicine, 2nd edition, p. 147. William Heinemann Medical Book Limited: London.

Westerman, M.P., Martinez, R.C., Medsger, T.A., $\stackrel{\rrbracket}{\varrho}$ TotTen, R.S. \& Rodnan, G.P. (1968) Anemia and sclero-.derma. Archives of Internal Medicine, 122, 39. 